\title{
O princípio da participação económica dos membros à luz dos novos perfis do escopo mutualístico
}

\author{
(The principle of member economic participation \\ in the light of the new profiles of the mutualistic scope)
}

\author{
Deolinda A. Meira ${ }^{1}$ \\ Instituto Politecnico do Porto / ISCAP / CECEJ (Portugal)
}

Sumário: 1. Delimitação do problema. 2. A questão do caráter vinculativo ou não vinculativo dos princípios cooperativos. 3. O princípio da participação económica dos membros no Código Cooperativo português. 4. O escopo não lucrativo da cooperativa. 5. A vantagem mutualista, excedentes e retornos. 5.1. A vantagem mutualista. 5.2. O retorno de excedentes como uma vantagem mutualista diferida. 5.3. A inexistência de um direito subjetivo ao retorno. 6. Resultados extracooperativos decorrentes de um escopo predominantemente mutualístico. 7. A difícil qualificação dos resultados provenientes de um escopo mutualístico indireto. 8. Os resultados extraordinários. 9. A necessária socialização do lucro nas cooperativas e seus requisitos. Conclusões. Bibliografia.

Summary: 1. Delimitation of the problem. 2. The question of the binding or non-binding nature of cooperative principles. 3 . The principle of the member economic participation in the Portuguese Cooperative Code. 4. The non-profit scope of the cooperative. 5. The mutual advantage, surpluses and patronage refunds. 5.1. The mutual advantage. 5.2. The patronage refunds as a deferred mutual advantage. 5.3. The absence of a subjective right of patronage refunds. 6 . Extracooperative results from a predominantly mutualistic scope. 7 . The difficult qualification of the results coming from an indirect mutualistic scope.8. The extraordinary results. 9. The necessary socialization of profit in cooperatives and their requirements. Conclusions. Bibliography.

1 Professora Adjunta do Instituto Politecnico do Porto / ISCAP / CECEJ. Correio eletronico: meira@iscap.ipp.pt. Correio postal: Instituto Superior de Contabilidade e Administracao do Porto, Rua de Jaime Lopes de Amorim, 4465-004 S. Mamede de Infesta,PORTUGAL. 
Resumo: O presente estudo pretende demonstrar que o princípio da participação económica dos membros apresenta uma visão redutora em matéria de determinação e distribuição dos resultados económicos nas cooperativas. A redação do princípio assenta na ideia de uma cooperativa "perfeita», que transaciona apenas com os seus cooperadores, prosseguindo um escopo exclusivamente e diretamente mutualístico. Nas últimas décadas, assistiu-se a uma reinvenção do modelo cooperativo, o que trouxe consigo alterações na configuração do escopo mutualístico das cooperativas. Estas podem operar com terceiros, podem desenvolver indiretamente, através de filiais societárias, atividade instrumental ou complementar da sua atividade principal, podem realizar operações situadas fora do seu objeto social. Deste modo, para além dos excedentes, as cooperativas podem produzir lucros. Para preservar o escopo mutualístico das cooperativas, deveria este princípio cooperativo conter orientações quanto à necessária socialização destes lucros, afetando-os obrigatoriamente a reservas irrepartíveis.

Palavras-chave: cooperativa, o princípio da participação económica dos membros, escopo mutualístico, excedentes, lucro, reservas irrepartíveis.

Abstract: This study aims to demonstrate that the principle of member economic participation presents a reductive vision for the determination and distribution of economic results in cooperatives. The wording of the principle is based on the idea of a "perfect» cooperative, which operates only with its members and pursues an exclusively and directly mutualistic scope. In recent decades, there has been a reinvention of the cooperative model, which brought with it changes in the cooperative mutualistic scope configuration. These may operate with third parties, may indirectly develop, through subsidiaries, instrumental or complementary activity of their main activity, and may carry out operations outside their cooperative purpose. Thus, in addition to surpluses, cooperatives can produce profits. In order to preserve the mutualistic scope of cooperatives, this cooperative principle should contain guidelines on the necessary socialization of these profits, obligatorily affecting them to indivisible reserves.

Keywords: cooperative, the principle of member economic participation, mutualistic scope, cooperative surpluses, profit, indivisible reserves. 


\section{Delimitação do problema}

Nos tempos atuais, as cooperativas enfrentam muitos desafios: não abdicar da identidade cooperativa, conseguir sustentabilidade, competir com agentes económicos de índole lucrativa numa economia aberta.

De forma a conseguir o equilíbrio entre estes propósitos o modelo cooperativo reinventou-se.

Nesta reinvenção não pode, contudo, a cooperativa abdicar da Identidade Cooperativa, conceito definido pela Aliança Cooperativa Internacional (ACI), em Manchester, em 1995 - a qual assenta num conjunto de sete princípios (os Princípios Cooperativos ${ }^{2}$ ) num conjunto de valores - (os Valores Cooperativos ${ }^{3}$ ) que enformam aqueles princípios e numa Noção de Cooperativa $4 / 5$.

Os princípios cooperativos refletem o que a cooperativa tem de mais específico, contendo o essencial da Identidade Cooperativa ${ }^{6}$.

Haverá que ter em conta que os princípios cooperativos são formulados pela $\mathrm{ACl}$ em termos vagos, são porosos, candidatos, por isso, a diferentes densificações e concretizações históricas ${ }^{7}$. Esta porosidade

2 Estes Princípios são os seguintes: adesão voluntária e livre; gestão democrática pelos membros; participação económica dos membros; autonomia e independência; educação, formação e informação; intercooperação; e interesse pela comunidade. Para uma análise desenvolvida destes princípios, v. Rui Namorado, Os Princípios Cooperativos (Coimbra: Fora do Texto, 1995), passim; e João Salazar Leite, Princípios Cooperativos (Lisboa: Imprensa Nacional Casa da Moeda, 2012), passim.

3 Os valores que funcionam como uma estrutura ética dos princípios cooperativos são: i) os valores de autoajuda, responsabilidade individual, democracia, igualdade, equidade e solidariedade, nos quais assenta a atividade das cooperativas como organizações; ii) os valores da honestidade, transparência, responsabilidade social e altruísmo que se dirigem ao comportamento individual dos cooperadores enquanto tais. V. Juan Luis Moreno, "Los valores según la Alianza Cooperativa Internacional (ACI)», CIRIEC-España, Revista Jurídica de Economía Social y Cooperativa, n. ${ }^{\circ} 25$ (2014): 371-393.

$4 \mathrm{~A} \mathrm{ACl}$ estabeleceu que "uma cooperativa é uma associação autónoma de pessoas unidas voluntariamente para prosseguirem as suas necessidades e aspirações comuns, quer económicas, quer sociais, quer culturais, através de uma empresa comum e democraticamente controlada».

5 V. Antonio Fici, "Cooperative Identity and the Law», European Business Law Review, n. ${ }^{\circ} 24$ (2013): 37-64.

6 V. Rui Namorado, Cooperatividade e Direito Cooperativo. Estudos e pareceres (Coimbra: Almedina, 2005), 10.

7 A raiz dos Princípios Cooperativos está na experiência cooperativa de Rochdale, iniciada em 1844, na região de Manchester, tendo no seu conjunto delimitado o próprio âmbito da $A C l$ na sua fundação, em 1895. A $A C l$ procedeu à sua redução a um texto formal (em 1937), reformulando-o posteriormente (em 1966 e em 1995). Na reformulação de 1995, a ACl integrou os Princípios numa Identidade Cooperativa. V. Leite, Princípios Cooperativos ...,1038. 
tem permitido, em alguns ordenamentos jurídicos, uma excessiva liberalização das leis cooperativas, associada a uma crescente contaminação societária do regime jurídico cooperativo.

Para repensar estes fenómenos, a ACl, na decorrência de uma Resolução da assembleia extraordinária, realizada em Manchester em 2012, definiu um «Plano para uma Década Cooperativa», também conhecido por ICA Blueprint for a Co-ooperative Decade 2012-2020, no qual se propôs repensar o conteúdo dos princípios cooperativos para o séc. XXI ${ }^{8}$.

Ora, quanto ao Princípio da participação económica dos membros, que constitui o objeto do nosso estudo, e no qual encontramos os pilares básicos que sustentam o regime económico das cooperativas (a referência ao capital e à sua propriedade comum; a remuneração limitada sobre o capital; e a aplicação dos excedentes), no documento "Guidance Notes to the Co-operative Principles»" ${ }^{9}$, de 2015, a ACl, quanto às matérias para futura reflexão não inclui a questão dos resultados económicos das cooperativas.

Como veremos, em termos de resultados económicos, este princípio centra-se na problemática do destino dos excedentes, assente na ideia de uma cooperativa "perfeita», que transaciona apenas com os seus cooperadores, prosseguindo um escopo exclusivamente e diretamente mutualístico.

Ora, atualmente, a legislação cooperativa prevê a possibilidade de as cooperativas desenvolverem, limitadamente, operações com terceiros e mesmo operações alheias aos fins próprios da cooperativa, com vista a aumentar a sua capitalização e sustentabilidade. Prevê-se, igualmente, a possibilidade de as cooperativas constituírem filiais societárias, através das quais desenvolvam uma parte da sua atividade (a chamada mutualidade indireta).

Efetivamente, a reinvenção do modelo cooperativo trouxe consigo alterações na configuração do escopo mutualístico das cooperativas. Este não tem de ser "exclusivamente mutualístico», podendo ser "predominantemente mutualístico». Não tem de ser prosseguido apenas por via direta, podendo excecionalmente, e desde que cumpridos determinados condicionalismos, ser prosseguido indiretamente. Estes novos perfis do escopo mutualístico geram, nas cooperativas, uma diversidade de resultados económicos.

8 Sobre este documento e sua análise crítica, v. Sascha H. Mölls e Hans-H. Münckner, ed., ICA Blueprint for a Co-ooperative Decade - a Critical Analysis (Marburg: Nomos, 2015), passim.

9 O documento pode ser consultado em: https://ica.coop/en/blueprint-themes/identity/guidancenote. 
Todos estes perfis do escopo mutualístico, bem como a diversidade de resultados económicos deles emergentes, estão presentes nos «Princípios PECOL», um projeto de iniciativa académica, conhecido como «Princípios do Direito Cooperativo Europeu», em inglês, Principles of European Cooperative Law. Estes princípios foram elaborados por um grupo de docentes e investigadores especialistas em direito cooperativo (SGECOL-Study Group on European Cooperative Law), depois de uma investigação comparada da legislação cooperativa e das melhores práticas em sete ordenamentos europeus (Alemanha, Espanha, Finlândia, França, Itália, Portugal e Reino Unido) ${ }^{10}$. O PECOL teve como objetivo específico a definição de um conjunto de princípios que possam ser reconhecidos e assumidos pelas organizações cooperativas e que possam constituir uma referência para o legislador aquando da regulação jurídica das cooperativas $^{11}$. Com este objetivo, os Princípios do Direito Cooperativo Europeu foram difundidos ${ }^{12}$ e debatidos com especialistas na área do Direito e organizações representativas das cooperativas europeias ${ }^{13}$, tendo sido publicados em setembro de 2017, por Intersentia Cambridge ${ }^{14}$.

O objetivo deste estudo é, assim, o de refletir sobre a necessidade de a redação do princípio da participação económica dos membros, sem abdicar da centralidade da participação económica dos membros na cooperativa, se adaptar às novas conceções legais e doutrinais do escopo cooperativo, cobrindo esta multiplicidade de operações e resultados económicos delas provenientes.

Para o efeito teremos em conta o regime jurídico português, o qual foi objeto de uma reforma recente, tendo sido aprovado, em 2015, um novo Código Cooperativo, pela Lei n. ${ }^{\circ}$ 119/2015, de 31 de

10 Sobre a criação do SGECOL, os objetivos do PECOL e o seu método de trabalho, ver Gemma Fajardo et al., «El nuevo grupo de estudio en Derecho Cooperativo Europeo y el proyecto "Los Principios del Derecho Cooperativo Europeo»», Revista de Derecho de Sociedades, n. ${ }^{\circ} 39$ (2012): 609-618.

11 A Aliança Cooperativa Internacional, no seu Plano de Ação para uma Década Cooperativa, publicado em 2012, por ocasião do Ano Internacional das Cooperativas, destacava que a investigação comparada sobre a legislação cooperativa na Europa desenvolvida pelo SGECOL «favorecerá a tomada de consciência e compreensão da legislação cooperativa no seio das comunidades jurídicas, universitárias e governamentais aos níveis nacional, europeu e internacional».

12 Os princípios do direito cooperativo europeu do SGECOL estiveram disponíveis em: http://www.euricse.eu/wp-content/uploads/2015/04/PECOL-May-2015.pdf

13 Destaque-se o Encontro: "Cooperative Law: The importance of a regulatory framework at the EU level», realizado em Bruxelas, na sede do Comité Económico e Social Europeu, no dia 9 de junho de 2015.

14 Gemma Fajardo et al., Principles of European Cooperative Law. Principles, Commentaries and National Reports (Cambridge: Intersentia, 2017. 
agosto ${ }^{15}$. Dado que esta reforma teve presente as novas tendências do direito cooperativo europeu, com particular destaque para os Princípios PECOL ${ }^{16}$, também estes serão tidos em conta nesta reflexão.

Para tanto, antes de identificar os diferentes perfis do escopo mutualístico e resultados económicos deles emergentes, dando particular destaque ao resultado cooperativo de referência, que é o excedente cooperativo, debruçar-nos-emos sobre aspetos gerais, como a questão do caráter vinculativo dos princípios cooperativos no ordenamento português e o conteúdo descritivo do princípio da participação económica dos membros.

\section{A questão do caráter vinculativo ou não vinculativo dos princípios cooperativos}

Na elaboração doutrinária acerca dos princípios cooperativos, destacam-se duas correntes: aqueles que entendem que os princípios cooperativos são normas obrigatórias, de caráter vinculativo para o legislador, o qual é obrigado a aderir a tais princípios, devendo implementá-los em normas jurídicas ${ }^{17}$; e aqueles que entendem que os princípios cooperativos são normas soft law ${ }^{18}$.

No ordenamento português, esta questão assume uma enorme relevância prática, dado que os princípios cooperativos são acolhidos pela Constituição da República Portuguesa (CRP) ${ }^{19}$.

15 Sobre a reforma de 2015 do Código Cooperativo português, v. Deolinda A. Meira e Maria Elisabete Ramos, "A reforma do Código Cooperativo em Portugal», Cooperativismo e Economía Social, n. ${ }^{\circ}$ 38(2016): 77-108.

16 Destacando essa influência, v. Gemma Fajardo, «La Cooperativa en la Unión Europea», em Sociedades Cooperativas, ed. por Alfredo Gonçalves Neto (São Paulo: LEX Editora, 2018), 550.

17 Em Portugal, Rui Namorado, Cooperatividade e Direito Cooperativo..., 67 e ss.: Em outros ordenamentos Francisco Vicent Chuliá, «El futuro de la legislación cooperativa», Cooperativismo e Economía Social, n. ${ }^{\circ} 24$ (2001-2002): 30; Maria Luísa LLobregat Hurtado, Mutualidad y empresas cooperativas (Barcelona: Bosch, 1990), 1113.

18 V. David Hiez, Coopératives. Création, Organisation, Fonctionnement (Paris: Éditions Delmas, Daloz, 2013), 46-49. Na mesma linha, Ger J. H. van der Sangen, «How to regulate cooperatives in the EU? A Theory of Path Dependency», The Dovenschmidt Quartely, International Review on Transitions in Corporate Life, Law and Governance, n. ${ }^{\circ} 4$ (2014): 139; Miguel Ángel Santos Dominguez, "La relación de los principios cooperativos con el Derecho, CIRIEC. Revista Jurídica de Economía Social y Cooperativa, n. ${ }^{\circ} 27$ (2015): 87 e ss.

19 Sobre o acolhimento jurídico-constitucional dos princípios cooperativos, v. Deolinda Aparício Meira, «O quadro jurídico-constitucional do cooperativismo em Portugal», Cooperativismo e Economía Social, n. ${ }^{\circ} 33$ (2011): 31-46. 
Assim, o art. $61 .^{\circ}$, n. ${ }^{\circ} 2$, da CRP dispõe que «a todos é reconhecido o direito à livre constituição de cooperativas, desde que observados os princípios cooperativos». Por sua vez, o art. 82. ${ }^{\circ},{ }^{\circ}{ }^{\circ} 4$, al. a), da CRP consagra que o subsetor cooperativo "abrange os meios de produção possuídos e geridos por cooperativas, em obediência aos princípios cooperativos».

A CRP não identifica os princípios cooperativos, sendo feita uma remissão expressa para os princípios definidos pela $\mathrm{ACl}$ e que estão descritos no art. 3. ${ }^{\circ}$ do Código Cooperativo português (CCoop): adesão voluntária e livre; gestão democrática pelos membros; participação económica dos membros; autonomia e independência; educação, formação e informação; intercooperação; e interesse pela comunidade.

Segundo Rui Namorado esta posição adotada na CRP põe à mercê das decisões da $\mathrm{ACl}$ a conformação do setor cooperativo português, pelo que quando a $\mathrm{ACl}$ alterar os princípios será a nova opção que passará a vigorar na ordem jurídica portuguesa ${ }^{20}$.

Nas palavras de Gomes Canotilho e Vital Moreira «As «cooperativas» que não respeitem estes princípios cooperativos não são verdadeiras cooperativas no sentido constitucional, não podendo gozar portanto das respetivas garantias» ${ }^{21}$.

No plano da legislação ordinária, o CCoop associa a noção de cooperativa (art. 2. ${ }^{\circ}$ do CCoop) à necessária obediência aos princípios cooperativos. Assim, nos termos do n. ${ }^{\circ} 1$ do art. $2 .^{\circ}$ do CCoop, serão cooperativas as «pessoas coletivas autónomas, de livre constituição, de capital e composição variáveis, que, através da cooperação e entreajuda dos seus membros, com obediência aos princípios cooperativos, visam, sem fins lucrativos, a satisfação das necessidades e aspirações económicas, sociais ou culturais daqueles».

Deste modo, o regime jurídico das cooperativas em Portugal deve assentar na observância de tais princípios cooperativos, enunciados no art. 3. ${ }^{\circ}$ do CCoop.

Os princípios cooperativos constituem, deste modo, o limite ao recurso ao direito subsidiário. De facto, o art. $9 .^{\circ}$ do CCoop, relativo ao direito subsidiário aplicável a situações nele não previstas, estabelece a possibilidade de recurso, "na medida em que se não desrespeitem os

20 V. Rui Namorado, As Cooperativas. Empresas que não são Associações (Faculdade de Economia da Universidade de Coimbra, 1999), 20.

21 Gomes Canotilho e Vital Moreira, Constituição da República Portuguesa anotada, vol. I (Coimbra: Coimbra Editora, 2007), 793. 
princípios cooperativos, ao Código das Sociedades Comerciais, nomeadamente aos preceitos aplicáveis às sociedades anónimas» ${ }^{22}$.

Neste contexto, no ordenamento português, a consagração jurídicoconstitucional dos princípios cooperativos, nos arts. $61 .{ }^{\circ}, \mathrm{n} .^{\circ} 2$ e $82 . .^{\circ}$, n. ${ }^{\circ} 4$, al. a) da CRP, confere-lhes uma força vinculativa e conformadora própria das normas jurídico-constitucionais. Segundo Gomes Canotilho e Vital Moreira, "Sendo a Constituição a norma suprema do país, todas as demais normas a devem respeitar ${ }^{23}$. Isto significa que o legislador ordinário está juridicamente obrigado a respeitar o sentido dos princípios cooperativos no momento em que produz normas jurídicas relativas ao regime jurídico das cooperativas. Em consequência, os atos legislativos do legislador ordinário que desrespeitem os princípios cooperativos estarão feridos de inconstitucionalidade (art. $277 .^{\circ}$, n. $^{\circ} 1$ da CRP24).

Na mesma linha, o CCoop dispõe que o desrespeito da cooperativa pelos princípios cooperativos, no seu funcionamento, constituirá causa de dissolução da mesma [al. h) do n. ${ }^{\circ} 1$ do art. $112 .^{\circ}$ do CCoop]. Trata-se de uma causa de dissolução compulsiva por via judicial.

Cabe à Cooperativa António Sérgio para a Economia Social (CASES), cooperativa de interesse público que congrega o Estado e diversas organizações da economia social, criada pelo Decreto-Lei n. ${ }^{\circ}$ 282/2009, de 7 de outubro, no exercício das suas funções de supervisão do setor cooperativo em Portugal (arts. $115 .^{\circ}$ a $118 .^{\circ}$ do CCoop), fiscalizar, nos termos da lei, a utilização da forma cooperativa, com respeito pelos princípios cooperativos, e normas relativas à sua constituição e funcionamento.

Para o efeito, as cooperativas estão obrigadas a remeter à CASES cópia dos atos de constituição e de alteração dos estatutos, dos relatórios anuais de gestão, dos documentos anuais de prestação de contas e do balanço social.

Assim, a CASES deverá requerer, através do Ministério Público, junto do tribunal competente, a dissolução das cooperativas que não respeitem, no seu funcionamento, os princípios cooperativos 25 .

22 V., neste sentido, Manuel Carneiro da Frada e Diogo Costa Gonçalves, "A acção ut singuli (de responsabilidade civil) e a relação do Direito Cooperativo com o Direito das Sociedades Comerciais», », Revista de Direito das Sociedades, n. ${ }^{\circ} 4$, Ano I (2009): 888-904.

23 Gomes Canotilho e Vital Moreira, Constituição da República Portuguesa anotada, 4. ${ }^{\text {a }}$ edição revista (Coimbra: Coimbra Editora, 2010), 881.

24 Esta norma estabelece que «São inconstitucionais as normas que infrinjam o disposto na Constituição ou os princípios nela consignados».

25 V., Deolinda Aparício Meira e Maria Elisabete Ramos, "Os princípios cooperativos no contexto da reforma do Código Cooperativo português», CIRIEC. Revista Jurídica de Economía Social y Cooperativa, n. 27 (2015): 407-409. 


\section{O princípio da participação económica dos membros no código cooperativo português}

No ordenamento português, o CCoop adota um sentido estritamente literal dos princípios cooperativos na construção do regime jurídico das cooperativas.

O Princípio da participação económica dos membros aparece descrito no art. $3 .^{\circ}$ do CCoop, tal como foi formulado pela $\mathrm{ACl}$, a saber: "Os membros contribuem equitativamente para o capital das suas cooperativas e controlam-no democraticamente. Pelo menos parte desse capital é, normalmente, propriedade comum da cooperativa. Os cooperadores, habitualmente, recebem, se for caso disso, uma remuneração limitada pelo capital subscrito como condição para serem membros. Os cooperadores destinam os excedentes a um ou mais dos objetivos seguintes: desenvolvimento das suas cooperativas, eventualmente através da criação de reservas, parte das quais pelo menos será indivisível; benefício dos membros na proporção das suas transações com a cooperativa; apoio a outras atividades aprovadas pelos membros».

Este princípio cooperativo fala numa contribuição equitativa para o capital das cooperativas que impende sobre todos os membros, consagrando a necessidade de essa contribuição se articular com o controlo democrático da cooperativa. Dele resulta que uma parte desse capital será propriedade coletiva da cooperativa e que o capital subscrito pelos membros poderá originar uma compensação limitada.

Em termos de resultados económicos, este princípio está direcionado exclusivamente para a problemática dos excedentes, dispondo que estes, a existirem, terão três possíveis destinos: o desenvolvimento da cooperativa, designadamente através da criação de reservas (parte das quais, será irrepartível); a distribuição pelos cooperadores proporcionalmente às operações realizadas com a cooperativa; o apoio a outras atividades que os membros aprovem ${ }^{26}$.

Omite-se qualquer referência aos resultados provenientes das operações com terceiros, das operações situadas fora do objeto social ou das operações desenvolvidas pelas filiais societárias detidas pelas cooperativas. Ainda que se fale da existência de um património irrepartível, o princípio não contem qualquer orientação quanto à obrigatoriedade de afetar esventais lucros obtidos pelas cooperativas às reservas irrepar-

26 Para uma análise deste principio e suas concretizações na legislação cooperativa, v. Gemma Fajardo, «Orientaciones y aplicaciones del principio de participación económica», CIRIEC. Revista Jurídica de Economía Social y Cooperativa, n. ${ }^{\circ} 27$ (2015): 205241. 
tíveis, tendo em conta o escopo não lucrativo das cooperativas, como veremos de seguida.

\section{O escopo não lucrativo da cooperativa}

A título principal, as cooperativas visarão "sem fins lucrativos, a satisfação das necessidades económicas, sociais e culturais» (art. 2. ${ }^{\circ}$, n. ${ }^{\circ} 1$, do (Coop) dos seus membros, que são os destinatários principais das atividades que esta leva a cabo.

Na mesma linha, na Secção 1.1 (1) do Capítulo I dos Princípios PECOL consta que "As cooperativas são pessoas coletivas de direito privado que exercem qualquer atividade económica que vise, sem fins lucrativos e a título principal, a satisfação das necessidades dos seus membros, enquanto consumidores, fornecedores ou trabalhadores da empresa cooperativa» 27 .

A título principal as cooperativas prosseguem um escopo mutualístico 28 .

As cooperativas são formadas por pessoas que querem cooperar entre si ou, mais especificamente, querem vender conjuntamente, trabalhar conjuntamente, consumir conjuntamente, prestar serviços conjuntamente. Para cumprir este propósito, constituem uma pessoa coletiva (a cooperativa) no âmbito da qual trabalham, consomem, vendem e prestam serviços.

Efetivamente, a cooperativa é criada com vista a eliminar o intermediário especulador, pela assunção direta, por parte dos cooperadores, da função da empresa, relegando -se assim o ente social (a cooperativa) para o papel de simples instrumento de articulação e ativação de um determinado grupo económico, com vista à obtenção de bens, serviços ou remunerações de trabalho em condições mais favoráveis do que seriam obtidas com a intervenção de intermediários ${ }^{29}$.

Esta instrumentalidade da cooperativa assenta, então, na ideia de que a atividade social da cooperativa se orienta necessariamente para

27 Gemma Fajardo et al., Principles of European Cooperative Law..., 19.

28 Sobre a distinção entre escopo mutualístico, escopo não lucrativo e escopo lucrativo, v. Antonio Fici, «El papel esencial del derecho cooperativo», CIRIEC. Revista Jurídica de Economía Social y Cooperativa, n. ${ }^{\circ} 27$ (2015): 23-33.

29 V., neste sentido, Cunha Gonçalves, Comentário ao Código Comercial português, volume I (Lisboa: Empreza Editora J.B., 1914), 541 e Sérvulo. Correia, «Elementos de um regime jurídico da cooperação», Estudos Sociais e Cooperativos, n. ${ }^{\circ}$ 17, Ano V (Março 1966): 162. 
os seus membros, que são os destinatários principais das atividades económicas e sociais que esta leva a cabo.

A cooperativa constitui-se "por e para os membros», com os quais opera no âmbito da atividade que a eles se dirige e na qual participam cooperando (chamada de atividade cooperativizada pela legislação e doutrina espanhola) ${ }^{30}$.

Esta participação traduzir-se-á num intercâmbio recíproco de prestações entre a cooperativa e os cooperadores, prestações essas que são próprias do objeto social da cooperativa.

$\mathrm{Na}$ decorrência do escopo mutualístico da cooperativa, estabelece-se, então, uma relação jurídica complexa, na qual se destaca, por um lado, a obrigação assumida pelo cooperador de participar na atividade da cooperativa e, por outro lado, a contraprestação realizada por esta.

Assim, o cooperador, diversamente do sócio de uma sociedade comercial, não estará apenas sujeitado à obrigação de entrada para o capital social da cooperativa, mas também à obrigação de participar na atividade da mesma. Neste sentido, o art. $22 .^{\circ}$, n. $^{\circ} 2$, al. c), do CCoop estabeleceu que os cooperadores deverão "participar em geral nas atividades da cooperativa e prestar o trabalho ou serviço que lhes competir, nos termos estabelecidos nos estatutos». Por sua vez. o PECOL estabelece, na Seção 1.4. (1) do Capítulo I que "As cooperativas prosseguem os seus objetivos principalmente através da realização de atividades com os seus membros cooperadores (atividade cooperativizada) para o fornecimento de bens, serviços ou trabalho», acrescentado n o n. ${ }^{\circ} 3$ desta secção que «Os estatutos da cooperativa devem incluir disposições sobre a participação dos membros cooperadores na atividade cooperativizada, designadamente quanto à extensão e/ou ao nível mínimos dessa participação» ${ }^{31}$.

Esta obrigação de participação na atividade da cooperativa surge como o mecanismo básico para desenvolver o objeto social da cooperativa e a obtenção da vantagem mutualista, como veremos no ponto seguinte.

30 Adotamos o conceito de atividade cooperativizada defendido por Carlos Vargas Vasserot, La actividad cooperativizada y las relaciones de la Cooperativa con sus sócios y con terceros, Monografía asociada a RdS, n. 27 (2006), 67, segundo o qual esta atividade se concretiza num conjunto de operações em que se verificam três circunstâncias, a saber: que sejam operações internas, isto é, que ocorram no âmbito da cooperativa; que sejam realizadas pelo cooperador com a cooperativa ou vice-versa; que estejam intimamente ligadas à prossecução do objeto social da cooperativa.

31 Gemma Fajardo et al., Principles of European Cooperative Law..., 40. 
Em suma, o fim da cooperativa não é a obtenção de lucros para depois os repartir, mas sim proporcionar aos seus membros vantagens diretas na sua economia individual.

\section{A vantagem mutualista, excedentes e retornos}

\subsection{A vantagem mutualista}

A cooperativa constitui-se para maximizar a vantagem que os membros retiram das operações que realizam com a cooperativa ou através da cooperativa.

O cooperador auferirá, em contrapartida pela sua participação na atividade cooperativizada, de vantagens económicas, às quais a doutrina chama de vantagens mutualistas ${ }^{32}$. Estas traduzir-se-ão na obtenção de determinados bens ou serviços a preços inferiores aos do mercado, na venda dos seus produtos eliminando os intermediários do mercado ou numa maior retribuição do trabalho prestado, tal como foi acima referido.

O momento em que o cooperador irá receber a vantagem mutualista, assim como o seu montante, dependerão, normalmente, da situação financeira que a cooperativa atravessa, assim como da estratégia de gestão económica adotada pela mesma. Neste sentido, a doutrina distingue entre vantagens imediatas - mediante a prática de preços mais baixos ou retribuições mais elevadas do que as praticadas no mercado - e vantagens diferidas - atribuídas no final do exercício mediante o retorno dos excedentes, de que falaremos a seguir ${ }^{33}$.

A cooperativa pode praticar preços muito próximos do custo, gerando excedentes insignificantes, ou até pode reforçar a qualidade do serviço prestado e as condições em que o mesmo é prestado, desvalorizando o apuramento de excedentes, sem que tal seja sinónimo de uma gestão deficiente ${ }^{34}$.

32 Sobre este conceito, v. Amadeo Bassi, «Dividendi e ristorni nelle società cooperative», Quaderni di Giurisprudenza Commerciale (Milano:Giuffrè Editore,1979),1 e ss.; e Franco Colombo e Pietro Moro, I ristorni nelle cooperative (Milano: II Sole 24 ore, 2004), 44 e ss.

${ }^{33} \mathrm{~V}$., neste sentido, Amadeo Bassi, «Dividendi e ristorni nelle società cooperative», ..., 2 .

34 Neste sentido, v. Gemma Fajardo, La gestión económica de la cooperativa: responsabilidad de los sócios (Madrid: Tecnos, 1997), 125-140; Manuel Paniagua Zurera, «Determinación y distribución de resultados en la sociedad cooperativa», Derecho de los Negocios, n. ${ }^{\circ} 66$ ( Año 7, marzo 1996): 3-4. 


\subsection{O retorno de excedentes como uma vantagem mutualista diferida}

À luz do princípio da participação económica dos membros, o retorno é apenas um dos destinos possíveis dos excedentes.

Mas o que deve entender-se por excedente?

O excedente cooperativo corresponde à diferença entre as receitas e os custos da atividade cooperativizada com os membros. Trata-se de um valor provisoriamente pago a mais pelos cooperadores à cooperativa ou pago a menos pela cooperativa aos cooperadores, como contrapartida da participação destes na atividade da cooperativa.

O excedente resulta, assim, de operações da cooperativa com os seus cooperadores, sendo gerado à custa destes, constituindo «o resultado de uma renúncia tácita dos cooperadores a vantagens cooperativas imediatas» 35 .

No PECOL, o excedente é definido como «a diferença entre as receitas e os custos da atividade cooperativizada com os membros» (Secção 3.6.(2) do Capítulo III) ${ }^{36}$.

Estas definições tornam evidente que o conceito de excedente cooperativo decorre da prossecução do escopo mutualístico pela cooperativa.

Assim, os excedentes anuais líquidos, de que se fala na al. b) do n. ${ }^{\circ} 2$ do art. $96 .^{\circ}$ do CCoop, reportam-se aos resultados cooperativos positivos relacionados com o escopo mutualístico prosseguido pela cooperativa.

Os excedentes poderão retornar aos cooperadores (n. ${ }^{\circ} 1$ do art. $100 .^{\circ}$ do (Coop). O retorno, entendido como o instrumento técnico de atribuição ao cooperador do excedente, surge, então, como uma distribuiçã̃o diferida da vantagem mutualista, significando a devolução ou a restituição que se faz ao cooperador, ao fazer o balanço e a liquidação do exercício económico, daquilo que já é seu desde o início da atividade. O retorno de excedentes funcionará, deste modo, como uma correção a posteriori, através da qual se devolverá, a quem formou o excedente, a diferença entre o preço praticado e o custo, ou a diferença entre as receitas líquidas e os adiantamentos laborais pagos, diferença esta determinada com exatidão no final de cada exercício.

Dada a participação económica dos cooperadores na atividade da cooperativa, a distribuição do retorno entre os cooperadores será feita

35 Rui Namorado, Cooperatividade e Direito Cooperativo..., 183.

36 Gemma Fajardo et al., Principles of European Cooperative Law..., 89. 
em função e proporcionalmente às atividades ou operações efetuadas com a cooperativa de que são membros (valor das compras ou serviços consumidos ou prestados, no caso das cooperativas de consumo ou de serviços; valor das transações efetuadas ou produtos entregues, no caso das cooperativas agrícolas ou de comercialização), ou em função e proporcionalmente ao trabalho de cada membro (como é o caso das cooperativas de trabalho, nas quais na distribuição do excedente gerado pelos membros deverão ser deduzidos os levantamentos já recebidos «por conta dos mesmos») ${ }^{37}$.

Nas sociedades comerciais, os dividendos distribuem-se entre os sócios na proporção da participação de cada um na sociedade, ou seja, na proporção da participação no capital social ${ }^{38}$. Na cooperativa, o excedente que cada cooperador gerou foi consequência da atividade que desenvolveu com a cooperativa e na mesma proporção do intercâmbio mutualístico, pelo que a cada cooperador corresponderá um retorno, proporcional também a esse intercâmbio.

Os lucros destinam-se a remunerar o investimento que foi feito pelos sócios e, por isso, serão distribuídos proporcionalmente à parte do capital social pertencente a cada sócio. Por sua vez, os excedentes não se destinam a remunerar o capital, mas apenas a compensar os cooperadores, na mesma medida em que estes contribuíram para que se gerassem os excedentes em causa.

A distribuição do retorno entre os cooperadores será, então, proporcional às operações feitas por cada um deles com a cooperativa, no referido exercício. Sendo os excedentes, resultantes de operações da cooperativa com os seus cooperadores, compreende-se, assim, que, quando ocorra o retorno, ele corresponda ao volume dessas operações e não ao número de títulos de capital que cada um detenha.

A distribuição na proporção das operações feitas com a cooperativa e não em função da participação no capital social terá, assim, a sua razão de ser na circunstância de que esses excedentes serão as vantagens cooperativas que o cooperador obteve precisamente ao fazer uso dos serviços que lhe presta a cooperativa, pelo que a propor-

37 V. Sobre esta questão, Hans-H Münkner, Co-operative Principles and Co-operative Law, 2nd, revised edition (Zurich: Lit Verlag GmbH \& Co. KG Wien, 2015), 147 e ss..

38 De acordo com o art. 22. ${ }^{\circ}$, n. ${ }^{\circ}$ 1, do Código das Sociedades Comerciais, os sócios participam nos lucros da sociedade segundo a proporção dos valores nominais das respetivas participações no capital. Este princípio pode ser livremente derrogado pelos sócios, por unanimidade, uma vez que a alteração da regra se traduzirá, em princípio, na atribuição de um direito especial a um sócio. 
ção que Ihe será atribuída estará em relação direta com o uso feito desses serviços.

Para além da orientação genérica consagrada no art. $3 .^{\circ}$, no sentido de uma repartição dos excedentes em «benefício dos membros na proporção das suas transações com a cooperativa», não encontramos no CCoop qualquer critério substancial explícito que regule a distribuição dos excedentes. O art. $100 .^{\circ}$, que se ocupa da distribuição dos excedentes, limita-se a afirmar que estes poderão "retornar aos cooperadores». Na legislação aplicável aos diferentes ramos, também não encontramos qualquer critério explícito de repartição, mas meras orientações genéricas. Assim, quanto às cooperativas culturais (Decreto-Lei n. ${ }^{\circ}$ 313/81, de 19 de novembro), dispõe-se, no seu art. 8. ${ }^{\circ}$, que aquela distribuição será «proporcional ao trabalho de cada membro» e que deverá obedecer "aos critérios definidos nos estatutos ou regulamentos internos». Quanto às cooperativas de produção operária (Decreto-Lei n. ${ }^{\circ}$ 309/81, de 16 de novembro), o art. 9. ${ }^{\circ}$ estabelece que, após a determinação dos excedentes, se deduzirão "os levantamentos dos membros recebidos por conta dos mesmos». Finalmente, o diploma que regula as cooperativas de serviços (DecretoLei n. ${ }^{\circ} 323 / 81$, de 4 de dezembro), estipula, no seu art. 9. ${ }^{\circ}$, que a distribuição dos excedentes, nas cooperativas de prestação de serviços, será feita "proporcionalmente ao trabalho de cada membro, segundo critérios definidos nos estatutos e/ou regulamentos internos da cooperativa, nos termos do art. $73 .^{\circ}$ do CCoop, deduzindo-se após a sua determinação, os levantamentos dos membros recebidos por conta dos mesmos».

Tal significa que o legislador se limitou a consagrar uma orientação genérica quanto à repartição dos excedentes, cabendo às cooperativas e aos cooperadores a definição concreta dos critérios de repartição dos excedentes nos estatutos, nos regulamentos internos, ou nas assembleias gerais das cooperativas.

Ao contrário do que acontece com as cooperativas, as sociedades comerciais não se constituem para negociar com os sócios, mas para tentar obter benefícios, através do estabelecimento de relações com pessoas que lhe são alheias. Logo, nas sociedades comerciais, os lucros são obtidos no mercado, nas transações com os clientes, fora do universo dos sócios.

Ora, nas cooperativas, como muito bem lembra Hans-H. MünkNER, "no fim de cada exercício, os excedentes realizados nas transações com os cooperadores clientes não são o resultado de esforços que procuram acumular um lucro na empresa cooperativa, à custa dos cooperadores clientes, porque nesse caso os cooperadores estariam a tentar 
realizar lucros à custa deles próprios» ${ }^{39}$. Como paradigma aponte-se o das cooperativas de produção, nas quais os excedentes são fruto do trabalho dos cooperadores e por eles repartidos na proporção do trabalho prestado. Mas também nas outras cooperativas a afirmação é plenamente válida, pois se existe excedente tal significa que o cooperador pagou ou recebeu um montante superior ou inferior ao praticado no mercado, renunciando a uma vantagem mutualista imediata.

Tal como já foi referido, os excedentes correspondem a uma vantagem mutualista diferida.

Uma nota final, a propósito da distinção entre lucro e excedente, reporta-se ao facto de nas sociedades comerciais a vantagem económica ser gerada à custa de terceiros, enquanto que nas cooperativas é gerada à custa dos próprios membros.

\subsection{A inexistência de um direito subjetivo ao retorno}

Tal como no direito societário, no qual se destaca a inexistência de um direito subjetivo à concreta repartição do lucro, também no direito cooperativo, será de defender que a inclusão, entre os direitos do cooperador, do direito ao retorno cooperativo (art. $100 .^{\circ}$, n..$^{\circ} 1$, do CCoop) não supõe o reconhecimento, a favor do cooperador, de um direito (concreto) a exigir a aplicação de parte dos excedentes disponíveis como retorno. A utilização, pelo legislador cooperativo português, da expressão "poderão retornar aos cooperadores» evidencia a possibilidade de que o direito ao retorno seja derrogado por deliberação da assembleia geral.

Confirmando esta inexistência de um direito subjetivo ao retorno, o PECOL, na Secção 2.3. (4. g.) ${ }^{40}$, prevê que os membros cooperadores têm o direito de "receber o retorno cooperativo nos termos da lei ou dos estatutos da cooperativa, depois de assim deliberado pelo órgão competente.

Destaque-se, ainda, que nas cooperativas uma percentagem do excedente de exercício, resultante das operações com os cooperadores, reverterá para a reserva legal [art. $96 .^{\circ}, \mathrm{n} .{ }^{\circ} 2$, al. b), do CCoop] e para a reserva para educação e formação cooperativa [art. $97 .^{\circ}$, n. $^{\circ} 2$, al. b), do CCoop], assim como para o eventual pagamento de juros pelos títulos de capital (art. 100. ${ }^{\circ}$ n. ${ }^{\circ} 1$, do CCoop).

39 Hans-H Münkner, Co-operative Principles and Co-operative Law ..., 148.

40 Gemma Fajardo et al., Principles of European Cooperative Law..., 53. 
Também no PECOL se dispõe que «uma percentagem do excedente anual líquido da cooperativa, sujeita, em princípio, a um limite fixado por lei ou pelos estatutos da cooperativa» reverte para a reserva legal e para a reserva de educação, formação e informação (Secção 3.4. (6 e 7) do Capítulo III) ${ }^{41}$.

Só depois de efetuadas estas reversões e pagamentos se estará em condições de apurar o retorno (art. 100. ${ }^{\circ}$, n. ${ }^{\circ} 1$, do CCoop).

Além disso, tal como nas sociedades comerciais, nas quais se houver reservas a formar ou a reconstituir, não poderão os sócios receber quaisquer quantias ou bens a título de lucros (arts. $32 .^{\circ}$ e $33 .^{\circ}$ do Código das Sociedades Comerciais), também nas cooperativas não se poderá proceder à distribuição de excedentes «antes de se terem compensado as perdas dos exercícios anteriores ou, tendo-se utilizado a reserva legal para compensar essas perdas, antes de se ter reconstituído a reserva ao nível anterior ao da sua utilização» (art. 100. ${ }^{\circ}$ n. ${ }^{\circ} 2$, do (Coop). Por outras palavras, o legislador impede a distribuição de excedentes quando e na medida em que forem necessários para cobrir prejuízos transitados ou para reconstituir a reserva legal.

Consagra-se, deste modo, um regime inderrogável de cobertura de prejuízos, devendo os excedentes de exercício ser afetados em primeira linha a tal finalidade.

Tal como nas sociedades comerciais, quanto ao lucro societário (arts. $31 .^{\circ}, 250 .^{\circ},{ }^{\circ}{ }^{\circ} 3$, e $386 .^{\circ},{ }^{\circ}{ }^{\circ} 1$, do Código das Sociedades Comerciais), também nas cooperativas as normas não determinam uma distribuição automática dos excedentes a título de retorno e, por isso, a distribuição não se operará sem uma deliberação social nesse sentido. No silêncio dos estatutos, tal deliberação de repartição deverá ser tomada por maioria dos votos emitidos, dado que é esta a regra para a aprovação da generalidade das deliberações (art. $40 .^{\circ}$, n. $^{\circ} 2$, do CCoop; e art. $386 .^{\circ}$ do CSC, aplicável por força do art. $9 .^{\circ}$ do CCoop).

Assim, havendo resultados positivos no exercício, será inequívoco o espaço de discricionariedade de que disporá a assembleia geral, quanto à aplicação dos mesmos.

Por um lado, a assembleia geral poderá optar livremente entre a distribuição pelos cooperadores ou pela formação de reservas. A assembleia poderá considerar que a política de constituição de reservas, com vista ao autofinanciamento (a grande opção que se contrapõe à distribuição), poderá ser muito mais conveniente, do ponto de vista dos cooperadores e da cooperativa.

41 Gemma Fajardo et al., Principles of European Cooperative Law..., 83. 
Por outro lado, a assembleia geral poderá determinar a retenção temporária de parte dos retornos individuais («retorno diferido», nas palavras de Ferreira da Costa ${ }^{42}$ ), para obviar à falta de capitais próprios suficientes. Este diferimento do retorno constituirá um empréstimo do cooperador à cooperativa, devendo, por isso, ser consentido pelo cooperador (art. 294. ${ }^{\circ}$, n. ${ }^{\circ}$ 2, do Código das Sociedades Comerciais, aplicável por remissão do art. $9 .^{\circ}$ do (Coop).

Tudo isto está em harmonia com o Princípio da participação económica dos membros (art. 3. ${ }^{\circ}$ do CCoop) que aponta três destinos possíveis para os excedentes: $10^{\circ}$ - «desenvolvimento das suas cooperativas»; $2^{\circ}$ - "apoio a outras atividades aprovadas pelos membros»; 3. - «distribuição dos excedentes em benefício dos membros na proporção das suas transações com a cooperativa». Daqui resultará que o retorno é um dos três destinos admitidos pelo legislador, no caso de se colocar essa hipótese, sendo que existe também a possibilidade de se conjugarem os três tipos de objetivos ou dois deles.

O direito ao retorno será por isso um direito derrogável do cooperador, estando, contudo, esta derrogabilidade limitada pelo Princípio geral do abuso de direito. Não poderá recusar-se a distribuição de excedentes sem mais e, também, não poderá fundar-se a recusa em motivos extrassociais, o que a acontecer poderá fundamentar ações de responsabilidade contra os membros do órgão de administração. A assembleia geral, em obediência aos princípios gerais de natureza contratual, designadamente ao Princípio da boa-fé, deve fundamentar a deliberação que afaste a distribuição de excedentes a título de retorno. Assim, a deliberação sobre a retenção dos excedentes no património da cooperativa terá de fundamentar-se no «interesse social», nomeadamente nas necessidades de autofinanciamento da cooperativa. Daqui resulta que tal deliberação será inválida se os cooperadores da maioria, com o seu voto, visarem prosseguir interesses extrassociais e, simultaneamente, prejudicarem interesses da cooperativa ou de outros cooperadores.

Esta inexistência de um direito subjetivo ao retorno dos excedentes tem repercussões de natureza fiscal. De facto, dadas as considerações precedentes, afigura-se lógica a decisão do legislador fiscal português de considerar o excedente como parte do património e dos resultados das cooperativas. Enquanto não se formaliza uma deliberação de pagamento dos excedentes aos membros da cooperativa, esta pode utilizar

42 Fernando Ferreira da Costa, Código Cooperativo. Benefícios fiscais e financeiros. Estatutos do Inscoop (Lisboa: Livraria Petrony, 1981), 94. 
esses excedentes afetando-os a novas finalidades de investimento ou de outro tipo ${ }^{43}$.

No entanto, se é verdade que a legislação cooperativa não impõe sobre as cooperativas a obrigatoriedade de retornar os excedentes aos cooperadores, nem permite esse retorno se houver perdas transitadas de exercícios anteriores, é igualmente certo que a mesma legislação deixa uma amplíssima margem para os estatutos cooperativos disporem sobre essa matéria. Com efeito, diz o n. 2 do artigo $16 .^{\circ}$ do CCoop (Elementos dos estatutos), na sua alínea e), que «os estatutos podem ainda incluir: (...) al. e) as normas de distribuição dos excedentes $(\ldots) »$.

Portanto, embora a lei não fixe qualquer obrigatoriedade de retorno de excedentes, nada impede que os estatutos estabeleçam essa obrigatoriedade, desde que se cumpram as limitações de constituição das reservas legal e de educação e de formação, bem como de cobertura de prejuízos nos termos acima mencionados.

\section{Resultados extracooperativos decorrentes de um escopo predominantemente mutualístico}

Nas cooperativas, para além dos resultados cooperativos, que são os resultados típicos destas, são identificáveis os resultados provenientes das operações com terceiros, que designamos de resultados extracooperativos.

De facto, o nexo teleológico existente entre a cooperativa e os seus membros não deverá ser entendido de um modo absoluto, ou seja, não deverá considerar-se a cooperativa como uma organização fechada, centrada apenas nos seus membros. Assim, o escopo mutualístico prosseguido pela cooperativa e que a distingue dos outros tipos sociais, não implica que esta desenvolva atividade exclusivamente com os seus membros, podendo atuar, igualmente, com terceiros, possibilidade que existia já na própria cooperativa de Rochdale ${ }^{44}$.

Estas relações contratuais com terceiros evidenciam, desde logo, a afirmação da sociabilidade reivindicada pela cooperativa: a cooperativa

${ }^{43}$ V. Nina Aguiar e Deolinda Meira, «Cooperative Income and ability to pay taxes A critical review», em Entidades com valor social: nuevas perspectivas tributarias, e. por Isaac Merino Jara (Madrid: Instituto de Estudios Fiscales, 2017), 145-157.

$44 \mathrm{~V}$., neste sentido, Charles Guide, Consumers'Co-operative Societies (Manchester: Co-operative Union Limited, 1921), 49 e ss.. 
satisfará, antes de mais, os interesses dos seus membros ao trabalho, ao crédito, à casa e, contemporaneamente, transbordará para o exterior, difundindo os seus serviços também a favor daqueles que, apesar de não serem membros da cooperativa, têm as mesmas necessidades que estes últimos, podendo, deste modo, gerar-se novas adesões ${ }^{45}$. Assim, na Secção 1.5. (4) do Capítulo I do PECOL, estabelece-se que « As cooperativas que desenvolvam operações com terceiros devem conceder-lhes a possibilidade de se tornarem membros cooperadores, devendo informá-los dessa possibilidade» ${ }^{46}$.

Por outro lado, este perfil não exclusivo da mutualidade permitirá às cooperativas tornarem-se mais competitivas, aumentado a sua capacidade financeira.

Nesta decorrência, o CCoop, no seu art. $2 .^{\circ}$, n. ${ }^{\circ} 2$, estabeleceu que "as cooperativas, na prossecução dos seus objetivos, poderão realizar operações com terceiros, sem prejuízo de eventuais limites fixados pelas leis próprias de cada ramo».

O CCoop eliminou, desta forma, a obrigatoriedade do caráter complementar da atividade com terceiros, que existia na legislação anterior (Decreto-Lei n. ${ }^{\circ} 454 / 80$, de 9 de outubro), na qual se dispunha que as cooperativas podiam «ainda, a título complementar, realizar operações com terceiros», ainda que seja de admitir que os estatutos possam proibir a realização de operações com terceiros. Neste sentido, no PECOL, na Secção 1.5. (2) do Capítulo I, dispõe-se que «as cooperativas podem realizar operações com terceiros, salvo disposição em contrário dos seus estatutos» ${ }^{47}$.

Nas palavras de Rui Namorado: "Terceiros, de um ponto de vista cooperativo, são todos aqueles que mantenham com uma cooperativa relações que se enquadrem na prossecução do seu objeto principal, como se fossem seus membros embora de facto não o sejam ${ }^{48}$.

Tal significa que as atividades com terceiros, de que fala o legislador, se reportarão a atividades do mesmo tipo da atividade cooperativizada desenvolvida com os cooperadores, pelo que as operações com terceiros estão ainda compreendidas no objeto social da cooperativa ${ }^{49}$.

45 V. Antonio Fici, «El papel esencial del derecho cooperativo»...,36-39.

46 Gemma Fajardo et al., Principles of European Cooperative Law..., 43.

47 Gemma Fajardo et al., Principles of European Cooperative Law..., 43.

48 Rui Namorado, Cooperatividade e Direito Cooperativo ..., 184-185.

49 V. Ana Maria Bandeira, Deolinda Meira e Vera Alves, "Los diferentes tipos de resultados en las cooperativas portuguesas. Un estudio de caso múltiple», REVESCO, n. ${ }^{\circ} 123$ (Primer Cuatrimestre 2017): 43 e ss.. http://dx.doi.org/10.5209/REVE.54919 
Confirmando esta nossa afirmação, no PECOL, na Secção 1.5. (1) do Capítulo I, afirma-se que "As operações com terceiros abrangem a atividade entre cooperativas e membros não-cooperadores (terceiros) para o fornecimento de bens, serviços ou trabalho, do mesmo tipo dos fornecidos aos membros cooperadores ${ }^{50}$.

No ordenamento português admite-se que as operações com terceiros possam ser objeto de limitações na legislação setorial dos diferentes ramos do setor cooperativo. Ora, ainda que previstas expressamente no art. 9..$^{\circ}$ do Decreto-Lei n. ${ }^{\circ}$ 523/99, de 10 de dezembro (cooperativas de comercialização), no art. $7 .^{\circ}$ do Decreto-Lei n. ${ }^{\circ} 313 / 81$, de 19 de novembro (cooperativas culturais), no art. $14 .^{\circ}$ do Decreto-Lei n. ${ }^{\circ}$ 502/99, de 19 de novembro (cooperativas de habitação e construção), no art. $6 .^{\circ}$ do Decreto-Lei n. ${ }^{\circ} 309 / 81$, de 16 de novembro (cooperativas de produção operária), no art. $6 .^{\circ}$ do Decreto-Lei n. ${ }^{\circ} 323 / 81$, de 4 de dezembro (cooperativas de serviços) e no art. 24. ${ }^{\circ}$, n. ${ }^{\circ} \mathrm{s} 2$ e 3 do Decreto-Lei n. ${ }^{\circ}$ 24/91, de 11 de janeiro (cooperativas de crédito agrícola), apenas esta última norma estabelece limites às operações de crédito com não associados (35\% do respetivo ativo líquido total, o qual poderá ser elevado para 50\%, mediante autorização do Banco de Portugal).

Os resultados positivos provenientes das operações com terceiros são lucros e, por isso, o legislador cooperativo português impediu que estes resultados sejam repartidos entre os cooperadores, quer durante a vida da cooperativa, quer no momento da sua dissolução (arts 100. n. ${ }^{\circ} 1$, e $114 .^{\circ}$ do (Coop), sendo transferidos integralmente para reservas irrepartíveis. Estamos perante lucros (objetivos); ainda que, por não serem distribuíveis pelos cooperadores, não se possa falar de escopo lucrativo, uma vez não há lucro subjetivo51.

Do exposto resulta que, quer no ordenamento português, quer nas novas tendências do direito cooperativo europeu, aqui representadas pelos Princípios PECOL, as cooperativas se caraterizarão por um escopo predominantemente, mas não exclusivamente, mutualístico, podendo desenvolver operações com terceiros ${ }^{52}$.

50 Gemma Fajardo et al., Principles of European Cooperative Law..., 43.

51 V. Deolinda Meira, "O regime económico das cooperativas à luz do no Código cooperativo português» Boletín de la Asociación de Derecho Cooperativo, n. ${ }^{\circ} 51$ (2016): 336-338. doi: http://dx.doi.org/10.18543/baidc-50-2016pp309-347

52 V. Deolinda Aparício Meira, "As operações com terceiros no Direito Cooperativo Português (Comentário ao Acórdão do Supremo Tribunal de Justiça de 18 de Dezembro de 2007)», Revista de Ciências Empresariais e Jurídicas, n. ${ }^{\circ} 17$ (2010): 93-111. 


\section{A difícil qualificação dos Resultados provenientes de um escopo mutualístico indireto}

Atualmente, admite-se que as cooperativas possam desenvolver uma parte da sua atividade não diretamente com os seus membros, no contexto da cooperativa, mas, indiretamente, através de sociedades comerciais controladas ou participadas pela própria cooperativa.

Ora, existem ordenamentos jurídicos que, a este propósito, falam de um conceito da «mutualidade indireta». Neste sentido, aponte-se o art. L.24.1 do Código Comercial Francês, na versão alterada de 200153, a Lei finlandesa de 2002, na qual o intercâmbio entre o sócio cooperador e uma sociedade controlada (pelo menos em 51\%) pela cooperativa é considerada, expressamente, como «mutualista», na condição de que a cooperativa detenha o controlo da sociedade ${ }^{54}$ e a Lei norueguesa, com as alterações de 2007, a qual estabelece, no art. 1. ${ }^{\circ}$, parágrafo terceiro, do Cooperative Act, 29 June 2007, n. 81, uma definição de mutualidade indireta, dispondo que "A cooperative society also exists if the interests of the members [...] are promoted through the members' trade with an enterprise, which the cooperative society owns alone or togheter with other cooperative societies, including a secondary cooperative [...]» 55 .

Acresce que nos Princípios PECOL, na Secção 1.1. (3) do Capítulo I, quando se define cooperativa se admite que «a empresa cooperativa possa incluir empresas detidas pela cooperativa através de uma filial, se tal for necessário para a satisfação das necessidades dos seus membros e desde que estes detenham o controlo dessa filial» ${ }^{56}$.

Já foi amplamente referido que as cooperativas têm um escopo mutualístico, uma vez que visam, a título principal, a satisfação das necessidades dos seus membros, enquanto consumidores, fornecedores ou trabalhadores da empresa cooperativa. Para tal, as cooperativas operam com os seus membros, no âmbito de uma atividade que a eles se dirige e na qual estes participam cooperando (mutualidade direita), como vimos.

53 V. David Hiez, «France», em International Handbook of Cooperative Law, ed. por Dante Cracogna, Antonio Fici e Hagen Henrÿ (Heidelberg: Springer, 2013), 393-411.

54 V. Hagen Henry, «Finland», em International Handbook of Cooperative Law ..., 373-382.

55 V. Tore Fjortoft e Ole Gjems-Onstad, «Norway and Scandinavian Countries», em International Handbook of Cooperative Law ..., 563-583.

56 Gemma Fajardo et al., Principles of European Cooperative Law..., 19. 
Parece-nos que o conceito de «mutualidade indireta» é compatível com o escopo mutualístico, desde que admitido com limites ou condições, de forma a afastar os riscos de desmutualização das cooperativas.

Efetivamente, se a atividade das cooperativas tiver sido transferida para a sociedade comercial sem quaisquer limites, podemos estar perante uma transformação encapotada da cooperativa em sociedade comercial, com a consequente violação do art. $111 .^{\circ}$ do CCoop, que proíbe a transformação da cooperativa numa sociedade comercial.

Com efeito, o art. $111 .{ }^{\circ}$ do CCoop dispõe que «É nula a transformação de uma cooperativa em qualquer tipo de sociedade comercial, sendo também feridos de nulidade os atos que contrariem ou iludam esta proibição legal».

Diversamente, será lícita, ao abrigo do art. $8 .^{\circ}$ do CCoop, a constituição de uma sociedade comercial por uma cooperativa ou em associação com outras cooperativas, provando-se que a sociedade comercial foi constituída para o desenvolvimento de atividades instrumentais, preparatórias ou complementares da atividade económica desenvolvida entre a cooperativa e os seus membros, mantendo a cooperativa a atividade principal que esteve na base da sua criação. A cooperativa segmenta as atividades que integram o seu objeto social, entregando uma ou mais dessas atividades a uma filial societária por si controlada ou participada.

Abstraindo das razões subjacentes à opção, que não cabem no âmbito deste estudo, o certo é que a legislação cooperativa portuguesa não reconhece expressamente o conceito de «mutualidade indireta», mas também não o proíbe. Por sua vez, e como já foi referido, este conceito é expressamente admitido nos Princípios PECOL.

Neste contexto, admitindo a possibilidade de que a cooperativa possa desenvolver o seu escopo mutualístico indiretamente, através de uma sociedade por si controlada ou na qual detém participações sociais conjuntamente com outras cooperativas, levanta-se o problema da classificação dos resultados provenientes dessa atividade económica. Será que os poderemos classificar como excedentes cooperativos?

Vimos, acima, que o excedente cooperativo é o termo utilizado na doutrina e na legislação para designar os resultados económicos positivos que decorrem da prossecução do escopo mutualístico pela cooperativa, correspondendo à diferença entre as receitas e os custos da atividade cooperativizada com os membros. Trata-se de um valor provisoriamente pago a mais pelos cooperadores à cooperativa ou pago a menos pela cooperativa aos cooperadores, como contrapartida da participação destes na atividade da cooperativa. 
Tendo em conta esta definição, parece, à primeira vista, que qualificar tais resultados como excedentes implicaria, desde logo, a negação da personalidade jurídica da sociedade comercial participada. A cooperativa e a sociedade comercial são duas entidades jurídicas distintas, com separação de patrimónios e com finalidades distintas.

Uma solução possível seria a de defender que os resultados provenientes destas operações desenvolvidas pelas sociedades controladas ou participadas por cooperativas deveriam ficar sujeitos ao regime previsto no CCoop para as operações com terceiros, acima referido.

No entanto, temos algumas reservas quanto à plena adequação desta solução. A dúvida persiste quanto aos resultados provenientes de operações que a cooperativa desenvolve indiretamente por sociedades comerciais por si detidas ou participadas conjuntamente com outras cooperativas e que se reportam a atividades situadas dentro do objeto social da cooperativa, que, ainda que sejam atividades instrumentais ou complementares, se revelam essenciais para a prossecução do escopo mutualístico. Hoje, parece-nos que a emergência destes grupos e a sua relevância em termos económicos imporá a necessidade de revisitar o regime de determinação e distribuição destes resultados na cooperativa e, eventualmente, discutir-se a possibilidade de, limitadamente, repartir uma parte destes resultados pelos cooperadores, aplicando analogicamente o regime previsto para o retorno cooperativo.

\section{Os resultados extraordinários}

Em termos de resultados positivos, refiram-se, finalmente, os resultados extraordinários, assim chamados porque são gerados em atividades situadas fora do objeto social da cooperativa. Aponte-se o exemplo de uma cooperativa que, extravasando o seu objeto, se dedica a uma atividade de especulação imobiliária ou adquire participações em sociedades, não para desenvolver atividade instrumental ou complementar, ao abrigo do conceito de "mutualidade indireta» acima referido, mas para realizar meros investimentos ${ }^{57}$.

Estas operações constituem instrumentos dirigidos a aumentar a capacidade da cooperativa ${ }^{58}$.

57 V. Ana Maria Bandeira, Deolinda Meira e Vera Alves, «Los diferentes tipos de resultados en las cooperativas portuguesas. Un estudio de caso múltiple», ...., 43 e ss..

58 V. Nina Aguiar, «A tributação do rendimento das cooperativas em Portugal», Cooperativismo e economía social, n. ${ }^{\circ} 36$ (2014): 66-72 
Sendo que estas operações se situam fora do objeto da cooperativa, os resultados delas provenientes deverão ser inequivocamente classificados como lucros (em sentido objetivo), impedindo-se, no entanto, e do mesmo modo que nas operações com terceiros, a sua repartição pelos membros cooperadores, sendo obrigatoriamente afetados a reservas irrepartíveis (não se podendo, por isso, falar de lucros em sentido subjetivo).

Esta tipologia de resultados tem gerado alguma polémica na jurisprudência portuguesa, nomeadamente no campo fiscal.

Cabe mencionar, a este respeito, uma recente decisão do Supremo Tribunal Administrativo de 16 de setembro de 2015, a propósito de uma operação de venda de terrenos por parte de uma cooperativa de produção de vinhos. A Fazenda Pública sustentava que se tratava de uma operação alheia aos fins próprios da cooperativa, interpretando esta expressão no sentido de objeto social da cooperativa. Contudo, o Tribunal sustentou uma diferente interpretação, declarando: "Assim é decisivo para a solução do presente pleito definir a natureza da atividade em causa, se alheia ou não aos fins cooperativos». Considerou o Tribunal que, como o produto da venda do terreno fora utilizado pela cooperativa para amortização dos seus compromissos financeiros, essa operação não era alheia aos fins próprios da mesma e, por isso, deveria estar isenta de imposto ${ }^{59}$.

Abstraindo da questão fiscal, que não cabe no âmbito do presente estudo, consideramos que estes resultados, do mesmo modo que os provenientes de operações com terceiros, não podem ser encarados como resultados de uma normal atividade de gestão da cooperativa, ainda que possam ser altamente convenientes à prossecução dos fins da cooperativa, ao aumentar a sua capitalização.

\section{A necessária socialização do lucro nas cooperativas e seus requisitos}

Do que se disse resulta que a legislação cooperativa proíbe o propósito do lucro a título principal, mas não a realização de operações lucrativas.

No entanto, deve o legislador obrigar à socialização dos lucros, de forma a não pôr em causa o escopo não lucrativo da cooperativa.

59 Sobre este acórdão, v. Nina Aguiar, «O problema da tributação do rendimento das cooperativas Reflexão a partir do direito português», Cooperativismo e economía social, n. 38 (2016): 182-187. 
Efetivamente, quer nas operações com terceiros, quer nas atividades que não correspondem ao objeto da cooperativa, quer nas atividades desenvolvidas através de filiais societárias que não correspondem a atividade complementar ou instrumental da atividade principal da cooperativa, para preservar o escopo mutualístico - acautelando uma transformação camuflada de uma cooperativa em uma sociedade comercial- deverá impedir-se que os resultados lucrativos provenientes daquelas operações sejam repartidos entre os cooperadores, quer durante a vida da cooperativa, quer no momento da sua dissolução, sendo transferidos integralmente para reservas irrepartíveis.

É esta a solução prevista, quer no ordenamento português, quer nos Princípios PECOL.

O art. 99. ${ }^{\circ}$ do CCoop estabelece a irrepartibilidade, pelos cooperadores, das reservas que resultem de benefícios provenientes de operações com terceiros.

Na Seção 1.5. (1) do Capítulo I dos Princípios PECOL, dispõe-se que "Os lucros provenientes das operações com terceiros são afetados a reservas irrepartíveis ${ }^{60}$. Por sua vez, na Secção 3.7. (1) do Capítulo III refere-se que «As cooperativas também podem obter outros resultados, incluindo resultados provenientes de operações com terceiros e resultados provenientes da titularidade de participações de capital em sociedades e outros ativos. Independentemente da sua origem, esses resultados são afetados a reservas irrepartíveis» ${ }^{61}$.

Obrigando à sua afetação a reservas irrepartíveis, que entre outros destinos serão utlizadas para aumentar a capacidade e a sustentabilidade da cooperativa, e consequentemente a promoção do cooperativismo, socializa-se o lucro obtido na cooperativa.

Esta socialização está, igualmente, presente no momento da liquidação do património da cooperativa.

Assim, o art. $114 .^{\circ}$ do CCoop dispôs, no seu n. ${ }^{\circ} 1$, que o montante da reserva legal —não afetado à cobertura das perdas de exercício e que não seja suscetível de aplicação diversa - «pode transitar com idêntica finalidade para a nova entidade cooperativa que se formar na sequência de fusão ou cisão da cooperativa em liquidação». Mas, nos termos do n. 3 do mesmo artigo do CCoop, estabeleceu-se que, «quando à cooperativa em liquidação não suceder nenhuma entidade cooperativa nova, a aplicação do saldo de reservas obrigatórias reverte para outra cooperativa, preferencialmente do mesmo município, a de-

60 Gemma Fajardo et al., Principles of European Cooperative Law..., 43.

61 Gemma Fajardo et al., Principles of European Cooperative Law..., 92. 
terminar pela federação ou confederação representativa da atividade principal da cooperativa». O n. ${ }^{\circ} 4$ foi ainda mais longe ao dispor que «às reservas constituídas nos termos do art. $98^{\circ}{ }^{\circ}$ deste Código é aplicável, em matéria de liquidação e no caso de os estatutos nada disporem, o estabelecido nos números 2 e 3 deste artigo», o que significa que este regime poderá abranger, igualmente, as reservas livres, caso os estatutos sejam omissos.

Na mesma linha, da Secção 3.8. (1 e 2) do Capítulo III do PECOL resulta que «Em caso de liquidação da cooperativa, e uma vez pagas as dívidas da mesma, os membros têm direito a recuperar somente o valor nominal dos seus títulos de capital e da sua quota-parte das reservas repartíveis, nos termos previstos nos estatutos da cooperativa. $\mathrm{O}$ montante reembolsável aos membros abrange, além do valor nominal dos seus títulos de capital, quaisquer juros e outros valores que lhes sejam devidos, nos termos previstos nos estatutos da cooperativa», sendo o ativo restante «repartido de acordo com o princípio da distribuição desinteressada» 62 .

Esta impossibilidade de distribuir o património residual, em caso de liquidação, deriva, desde logo, da função social que a cooperativa é chamada a cumprir e que implica que o seu destino, após a liquidação, seja a promoção do cooperativismo (o chamado Princípio da distribuição desinteressada) ${ }^{63}$.

Em todo o caso, o que é certo é que a admissibilidade das operações com terceiros, de operações situadas fora do objeto da cooperativa, de operações desenvolvidas através de filiais societárias, gera uma diversidade de resultados económicos, pelo que a cooperativa terá de adotar uma contabilidade separada que permita distinguir claramente os excedentes - resultantes das operações com os cooperadores dos lucros - provenientes das operações com terceiros ou das operações extraordinárias. Esta contabilidade separada permitirá que a cooperativa contabilize, sem perigo de confusão, o património repartível e o irrepartível.

Ora, no ordenamento português, nem o CCoop nem a legislação contabilística aplicável às cooperativas em Portugal (Sistema de Normalização Contabilística-SNC) ${ }^{64}$ se pronunciaram sobre esta questão, pelo que continua a ser possível, no estado atual da legislação, a não

62 Gemma Fajardo et al., Principles of European Cooperative Law..., 93.

63 Para uma análise desenvolvida deste princípio, v. María Luisa Llobregat Hurtado, Mutualidad y empresas cooperativas (Barcelona: Bosch, 1990), 374 e ss..

64 Decreto-Lei n. ${ }^{\circ}$ 158/2009, de 13 de julho [que aprovou o SNC], alterado pelo Decreto-Lei n. ${ }^{\circ}$ 86/2015, de 11 de março. 
adoção de uma contabilização separada das operações com membros, com terceiros e operações extraordinárias, com as consequentes dificuldades em termos de controlo e fiscalização quanto à proveniência, distribuição e afetação dos resultados económicos das cooperativas.

Já nos Princípios PECOL, na Secção 1.5. (4) do Capítulo I dispõe-se que «Quando as cooperativas realizem operações com terceiros, devem organizar uma contabilidade separada dessas operações» ${ }^{65}$.

\section{Conclusões}

O princípio da participação económica dos membros assenta numa visão redutora em matéria de determinação e distribuição dos resultados nas cooperativas.

Centrando-se apenas na problemática do destino dos excedentes, este princípio parte da ideia de uma cooperativa "perfeita», que transaciona apenas com os seus cooperadores, prosseguindo um escopo exclusiva e diretamente mutualístico.

Do intercâmbio mutualístico poderão resultar excedentes, os quais poderão retornar aos cooperadores, sem que se possa afirmar que existe um direito subjetivo ao retorno dos excedentes. Todavia, os excedentes não são lucros nem os retornos dividendos. Estamos perante uma distribuição diferida da vantagem mutualista, pelo que o retorno dos excedentes significa a devolução ou a restituição que se faz ao cooperador, ao fazer o balanço e a liquidação do exercício económico, daquilo que já é seu desde o início da atividade.

A menos que os estatutos o proíbam, as cooperativas podem limitadamente desenvolver operações com terceiros, possibilidade que remonta à própria Cooperativa de Rochdale. Estas operações com terceiros reportam-se a atividades do mesmo tipo da atividade desenvolvida com os cooperadores, pelo que estão ainda compreendidas no objeto social da cooperativa. Acresce que estas operações poderão permitir a expansão da cooperativa, gerando novas adesões, bem como aumentar a sua capacidade financeira, permitindo à cooperativa prosseguir de forma mais sustentável o seu escopo mutualístico.

Fala-se, por isso de um escopo predominantemente mutualístico.

Também se admite que a cooperativa possa incluir empresas por ela detidas através de uma filial, se tal for necessário para a satisfação das necessidades dos seus membros e desde que estes detenham o

65 Gemma Fajardo et al., Principles of European Cooperative Law..., 43. 
controlo dessa filial, pelo quo o escopo mutualístico também pode ser prosseguido indiretamente.

Finalmente, permite-se que as cooperativas realizem operações situadas fora do seu objeto social, desde que visem aumentar a capacidade da cooperativa.

Os resultados provenientes destas operações são lucros, que, em nome da preservação da identidade cooperativa, não podem ser repartidos entre os cooperadores, quer durante a vida da cooperativa, quer no momento da sua dissolução, sendo transferidos integralmente para reservas irrepartíveis. Para o efeito, devem as cooperativas organizar uma contabilidade separada dessas operações.

É esta a solução prevista quer no ordenamento português quer nos Princípios PECOL.

Neste contexto, entendemos como necessária uma redação mais abrangente do princípio da participação económica dos membros que, sem abdicar da centralidade da participação dos membros na cooperativa e dos excedentes enquanto resultados cooperativos típicos, se adapte às novas conceções legais e doutrinais do escopo cooperativo, cobrindo esta multiplicidade de operações e resultados económicos delas provenientes.

\section{Bibliografia}

AGUIAR, Nina. 2014. "A tributação do rendimento das cooperativas em Portugal», Cooperativismo e economía social, n. ${ }^{\circ} 36$, pp. 55-80.

AGUIAR, Nina. 2016. "O problema da tributação do rendimento das cooperativas - Reflexão a partir do direito português», Cooperativismo e economía social, n. ${ }^{\circ} 38$, pp. 163-190.

AGUIAR, Nina e Meira, Deolinda. 2017. "Cooperative Income and ability to pay taxes - A critical review», em Entidades con valor social: nuevas perspectivas tributarias, ed. por Isaac Merino Jara. Madrid: Instituto de Estudios Fiscales, pp. 145-157.

BANDEIRA, Ana Maria, Meira, Deolinda e Alves, Vera. 2017. «Los diferentes tipos de resultados en las cooperativas portuguesas. Un estudio de caso múltiple», REVESCO. Revista de estudios cooperativos, n. ${ }^{\circ} 123$, pp. 37-63. http://dx.doi.org/10.5209/REVE.54919

BASSI, Amadeo. 1979. «Dividendi e ristorni nelle società cooperative», Quaderni di Giurisprudenza Commerciale. Milano:Giuffrè Editore.

CANOTILHO, Gomes e Moreira, Vital. 2007. Constituição da República Portuguesa anotada, vol. I. Coimbra: Coimbra Editora.

CANOTILHO, Gomes e Moreira, Vital. 2010. Constituição da República Portuguesa anotada, 4. ${ }^{a}$ edição revista. Coimbra: Coimbra Editora. 
COLOMBO, Franco e Moro, Pietro. 2004. I ristorni nelle cooperative. Milano: II Sole 24 ore.

CORREIA, Sérvulo. 1966. «Elementos de um regime jurídico da cooperação», Estudos Sociais e Cooperativos, n. ${ }^{\circ} 17$, pp. 110-174.

COSTA, Fernando Ferreira da. 1981. Código Cooperativo. Benefícios fiscais e financeiros. Estatutos do Inscoop. Lisboa: Livraria Petrony.

FAJARDO, Gemma. 1997. La gestión económica de la cooperativa: responsabilidad de los sócios. Madrid: Tecnos.

FAJARDO, Gemma et al. 2012. «El nuevo grupo de estudio en Derecho Cooperativo Europeo y el proyecto «Los Principios del Derecho Cooperativo Europeo»», Revista de Derecho de Sociedades, n. ${ }^{\circ} 39$, pp. 609-618.

FAJARDO, Gemma. 2015. «Orientaciones y aplicaciones del principio de participación económica», CIRIEC. Revista Jurídica de Economía Social y Cooperativa, n. ${ }^{\circ} 27$, pp. $205-241$.

FAJARDO, Gemma et al. 2017. Principles of European Cooperative Law. Principles, Commentaries and National Reports. Cambridge: Intersentia.

FAJARDO, Gemma. 2018. "La Cooperativa en la Unión Europea», em Sociedades Cooperativas, ed. por Alfredo Gonçalves Neto, São Paulo: LEX Editora, pp. 537-566.

$\mathrm{FICl}$, Antonio. 2013. "Cooperative Identity and the Law», European Business Law Review, n. ${ }^{\circ}$ 24, pp. 37-64.

$\mathrm{FICl}$, Antonio. 2015. "El papel esencial del derecho cooperativo», CIRIEC. Revista Jurídica de Economía Social y Cooperativa, n. ${ }^{\circ} 27$, pp. 13-47.

FJORTOFT, Tore e Gjems-Onstad, Ole. 2013. «Norway and Scandinavian Countries», em International Handbook of Cooperative Law, ed. por Dante Cracogna, Antonio Fici e Hagen Henrÿ. Heidelberg: Springer, pp. 563-583.

FRADA, Manuel Carneiro da e Gonçalves, Diogo Costa. 2009. "A acção ut singuli (de responsabilidade civil) e a relação do Direito Cooperativo com o Direito das Sociedades Comerciais»,», Revista de Direito das Sociedades, n. ${ }^{\circ} 4$, Ano I, pp. 888-904.

GONÇALVES, Cunha. 1914. Comentário ao Código Comercial português, volume I. Lisboa: Empreza Editora J. B..

GUIDE, Charles. 1921. Consumers'Co-operative Societies. Manchester: Co-operative Union Limited.

HENRY, Hagen. 2013. «Finland», em International Handbook of Cooperative Law, ed. por Dante Cracogna, Antonio Fici e Hagen Henrÿ. Heidelberg: Springer, pp. 373-382.

HIEZ, David. 2013. Coopératives. Création, Organisation, Fonctionnement. Paris: Éditions Delmas, Daloz.

HIEZ, David. 2013. "France», em International Handbook of Cooperative Law, ed. por Dante Cracogna, Antonio Fici e Hagen Henrÿ. Heidelberg: Springer, pp. 393-411.

LEITE, João Salazar. 2012. Princípios Cooperativos. Lisboa: Imprensa Nacional Casa da Moeda.

LLOBREGAT HURTADO, Maria Luísa. 1990. Mutualidad y empresas cooperativas. Barcelona: Bosch. 
MEIRA, Deolinda Aparício. 2010. «As operações com terceiros no Direito Cooperativo Português (Comentário ao Acórdão do Supremo Tribunal de Justiça de 18 de Dezembro de 2007)», Revista de Ciências Empresariais e Jurídicas, n. ${ }^{\circ} 17$, pp. 93-111.

MEIRA, Deolinda Aparício. 2011. «O quadro jurídico-constitucional do cooperativismo em Portugal», Cooperativismo e Economía Social, n. ${ }^{\circ} 33$, pp. 31-46.

MEIRA, Deolinda Aparício e Ramos, Maria Elisabete. 2015. "Os princípios cooperativos no contexto da reforma do Código Cooperativo português», CIRIEC. Revista Jurídica de Economía Social y Cooperativa, n. ${ }^{\circ} 27$, pp. 401 427.

MEIRA, Deolinda. 2016. «O regime económico das cooperativas à luz do no Código cooperativo português» Boletín de la Asociación Internacional de Derecho Cooperativo, n. ${ }^{\circ}$ 51, pp. 309-348. doi: http://dx.doi. org/10.18543/baidc-50-2016pp309-347

MEIRA, Deolinda A. e Ramos, Maria Elisabete. 2016. «A reforma do Código Cooperativo em Portugal», Cooperativismo e Economía Social, n. ${ }^{\circ} 38$, pp. 77-108.

MÖLLS, Sascha H. e Hans-H. Münckner, Hans-H.. ed. 2015. ICA Blueprint for a Co-ooperative Decade - a Critical Analysis, Marburg: Nomos.

MORENO, Juan Luis. 2014. "Los valores según la Alianza Cooperativa Internacional (ACI)», CIRIEC-España, Revista Jurídica de Economía Social y Cooperativa, $n{ }^{\circ} 25$, pp. 371-393.

MÜNKNER, Hans-H. 2015. Co-operative Principles and Co-operative Law, 2nd, revised edition. Zurich: Lit Verlag GmbH \& Co. KG Wien.

NAMORADO, Rui. 1995. Os Princípios Cooperativos. Coimbra: Fora do Texto.

NAMORADO, Rui. 1999. As Cooperativas. Empresas que não são Associações. Faculdade de Economia da Universidade de Coimbra.

NAMORADO, Rui. 2005. Cooperatividade e Direito Cooperativo. Estudos e pareceres. Coimbra: Almedina.

PANIAGUA ZURERA, Manuel. 1996. «Determinación y distribución de resultados en la sociedad cooperativa», Derecho de los Negocios, n. ${ }^{\circ} 66$, pp. 1-12.

SANGEN, Ger J. H. van der. 2014. "How to regulate cooperatives in the EU? A Theory of Path Dependency», The Dovenschmidt Quartely, International Review on Transitions in Corporate Life, Law and Governance, n. ${ }^{\circ} 4$, pp. 131-146.

SANTOS DOMINGUEZ, Miguel Ángel. 2015. "La relación de los principios cooperativos con el Derecho, CIRIEC. Revista Jurídica de Economía Social y Cooperativa, n. ${ }^{\circ} 27$, pp. 87-132.

VARGAS VASSEROT, Carlos. 2006. La actividad cooperativizada y las relaciones de la Cooperativa con sus sócios y con terceros, Monografía asociada a $R d S, n .^{\circ} 27$.

VICENT CHULIÁ, Francisco. 2001-2002. «El futuro de la legislación cooperativa», Cooperativismo e Economia Social, n. ${ }^{\circ} 24$, pp. 7-42. 


\section{Derechos de autor}

El Boletín de la Asociación Internacional de Derecho Cooperativo es una revista de acceso abierto lo que significa que es de libre acceso en su integridad inmediatamente después de la publicación de cada número. Se permite su lectura, la búsqueda, descarga, distribución y reutilización legal en cualquier tipo de soporte sólo para fines no comerciales y según lo previsto por la ley; sin la previa autorización de la Editorial (Universidad de Deusto) o el autor, siempre que la obra original sea debidamente citada (número, año, páginas y DOI si procede) y cualquier cambio en el original esté claramente indicado.

\section{Copyright}

The International Association of Cooperative Law Journal is an Open Access journal which means that it is free for full and immediate access, reading, search, download, distribution, and lawful reuse in any medium only for non-commercial purposes, without prior permission from the Publisher or the author; provided the original work is properly cited and any changes to the original are clearly indicated. 